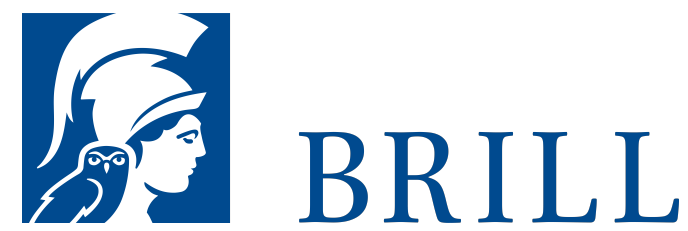

\title{
Australian Fiction as Archival Salvage
}

Making and Unmaking the Postcolonial Novel

Author: Frances A. Johnson

Australian Fiction as Archival Salvage examines key developments in the field of the Australian postcolonial historical novel from 1989 to the present. In parallel with this analysis, A. Frances Johnson undertakes a unique study of inkind creativity, reflecting on how her own nascent historical fiction has been critically and imaginatively shaped and inspired by seminal experiments in the genre - by writers as diverse as Kate Grenville, Mudrooroo, Kim Scott, Peter Carey, Richard Flanagan, and Rohan Wilson.

Mapping the postcolonial novel against the impact of postcolonial cultural theory and Australian writers' intermittent embrace of literary postmodernism, this survey is also read against the post-millenial 'history' and 'culture wars' which saw politicizations of national debates around history and fierce contestation over the ways stories of Australian pasts have been written.

\section{Readership}

Academic readers and undergraduates/postgraduates across fields including: Literary Studies, Creative Writing, Australian Studies and Postcolonial Studies. The book will also be of benefit to creative writing lecturers requiring solid context on the generic trajectories of the historical novel and on key historiographical debates pertaining to postcolonial narrative, Australian history and literature.

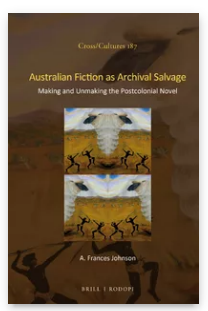

Pages: xxxii, 319 pages

Language:

English

Subjects:

Literature, Arts

\& Science,

Literature and

Cultural Studies, Criticism \&

Theory,

Literature and

Cultural Studies,

Postcolonial

Literature \&

Culture,

Literature and

Cultural Studies,

Postmodernism,

Literature and

Cultural Studies

Publisher: Brill

Series:

Cross/Cultures,

Volume: 187

E-Book (PDF)

Released online:

16 Nov 2015

ISBN: 978-90-

o4-31167-1

List price

USD \$144.00

Hardback 
A. Frances Johnson, Ph.D (2009), The University of Melbourne, ISBN: $978-90-$ is a prize-winning poet and novelist and head of the Creative Writing program at the University of Melbourne. She has published widely on portrayals of colonial Indigenous figures in Australian literature. Her novel Eugene's Falls (Arcadia, 2007) retraced the journeys of 19th century colonial painter Eugene von Guerard. A new novel in progress explores French firstcontact histories in Southern Tasmania.

For more information see brill.com

Order information: Order online at brill.com +44330 3330049 | customerservices@brill.com Submission information: brill.com/authors

Titles published by Brill | Fink, Brill | mentis or Brill | Schöningh: +49(o)71 5413279216 | brill@brocom.de

04-30997-5

List price

USD $\$ 144.00$ 